\title{
Land and Freshwater Molluscs
}

\author{
Paul Davies
}

\section{Introduction}

Any study of past extinctions and introductions is based upon a sound knowledge of the current distribution of species. From its inception in 1876 , The Conchological Society of Great Britain and Ireland had a strong interest in species' geographical distribution and was able to build upon earlier work at a county level (e.g. Lowe I853, and others quoted in Kerney 1999). In 196I the Society formally launched its latest major national mapping initiative based upon to $\mathrm{km}$ national grid squares, with the preliminary results published in Kerney (1976) and a more detailed update published in Kerney (1999). As pointed out in the 1999 update, the level of detail which we know about molluscan distributions in the British Isles and Ireland is probably unparalleled with comparison to any other invertebrate group.

The national mapping scheme has given us a superb database of what species presently live where within Britain and Ireland. Above and beyond that, the scheme has also incorporated fossil occurrences from molluscan studies concerned with late-Quaternary landscape change (e.g. Kerney et al. I980; Preece 1980) and with the setting of prehistoric archaeological sites (e.g. Evans 1999; Evans et al. 1988). The combination of modern and past occurrences within the scheme has allowed us to determine whether species are likely to be native (that is, arrived in the British Isles under their own powers of dispersal), probably native (likely to have arrived under their own accord but not definitively proven to have done so by the fossil record), or are introductions (brought here by accident or deliberate introduction, Tables I2 and I3). It also clearly highlights some species that the fossil record shows were here in the past but for which there are no modern records (i.e. they are now extinct in Britain and Ireland, Table I4). However, it is necessary to point out that this has only been possible for those molluscan species with a recognisable shell, since it is the shell that is preserved in ancient deposits. While the present distribution of non-shelled Mollusca (i.e. slugs) is therefore known, the fossil record is unable to shed light on their native or non-native status. 


\begin{tabular}{|c|c|c|}
\hline Period in which introduced & Species & Notes \\
\hline \multirow[t]{2}{*}{ Prehistory } & Cocblicella acuta & $\begin{array}{l}\text { Most probably a late prehistoric introduction. Present in a pre- } \\
\text { later Iron Age soil at Stackpole Warren, Dyfed (Benson et al. } \\
\text { 1990). }\end{array}$ \\
\hline & Monacha cartusiana & A 'weed' species present from the Neolithic period onward. \\
\hline \multirow[t]{7}{*}{ Roman/Romano-British } & Oxychilus draparnaudi & A Mediterranean species. \\
\hline & Balea biplicata & $\begin{array}{l}\text { Known from a few Roman sites only and presently restricted to } \\
\text { the Thames area near London. }\end{array}$ \\
\hline & Candidula gigaxii & A 'weed' species. \\
\hline & Cernuella virgata & A 'weed' species. \\
\hline & Monacha cantiana & A 'weed' species probably introduced in the late Roman period. \\
\hline & Helix aspersa & $\begin{array}{l}\text { A mainly Mediterranean species probably introduced accidentally } \\
\text { via trade routes. }\end{array}$ \\
\hline & Helix pomatia & Probably introduced during the Roman period for food. \\
\hline \multirow[t]{3}{*}{ Medieval } & Oxychilus helveticus & Known only from Post-Roman sites. \\
\hline & Cecilioides acicula & $\begin{array}{l}\text { A Mediterranean species. Although found in prehistoric deposits } \\
\text { the species can burrow to about } 2 \mathrm{~m} \text { and it is therefore probably } \\
\text { intrusive in pre-Medieval deposits. }\end{array}$ \\
\hline & Candidula intersecta & No pre-Medieval records in the UK. \\
\hline \multirow[t]{9}{*}{ Recent } & Paralaoma caputspinulae & First recorded in 1985. Originally Australasian. \\
\hline & Helicodiscus singleyanus & First recorded in 1975. Origin in North America. \\
\hline & Semilimax pyrenaicus & $\begin{array}{l}\text { Found in Ireland only. Probably an 18th or 19th Century } \\
\text { introduction. }\end{array}$ \\
\hline & Bradybaena fruticum & $\begin{array}{l}\text { A 20th Century introduction with a few occurrences recorded in } \\
\text { south east England. Now probably extinct. }\end{array}$ \\
\hline & Trochoidea elegans & Recorded in 1890 from Kent. \\
\hline & Cocblicella barbara & $\begin{array}{l}\text { Probably introduced in the } 1970 \text { s. Restricted to a few south- } \\
\text { western coastal parts of the UK }\end{array}$ \\
\hline & Hygromia cinctella & $\begin{array}{l}\text { First recorded at Paignton, Devon in } 1950 . \text { The species is now } \\
\text { expanding northwards. }\end{array}$ \\
\hline & Hygromia limbata & First recorded in 1917 in Devon. Now spreading northwards. \\
\hline & Theba pisana & $\begin{array}{l}\text { A Mediterranean 'weed' species probably introduced in the 19th } \\
\text { Century. }\end{array}$ \\
\hline
\end{tabular}

\section{Late-Glacial and Postglacial faunal changes}

Studies of well-dated fossil sequences have allowed a very detailed picture of molluscan colonisation of the British Isles and Ireland since the last glacial period. Kerney (1977) first proposed molluscan biozones (in effect the molluscan equivalent of the well established Late-glacial and postglacial pollen zones) for south-eastern England, and these have since been amended in the light of further intensive study and dating at Holywell Coombe near Folkestone (Preece and Bridgland 1998; 1999). The molluscan biozones are set out in Table I5.

As one would expect, these biozones clearly mirror the climatically-driven vegetation changes in the Late-glacial to mid-postglacial periods, with opencountry, cold-climate faunas (Zones $y$ and $z$ ) giving way to shade-tolerant or shade-demanding faunas indicative of mid-postglacial temperate woodland (Zones $a-d)$. The most recent zones $(e-f)$ show the re-emergence and expansion
TABLE I2. Introduced terrestrial species. Data from Kerney (1999). 
TABLE I3. Introduced freshwater species. Data from Kerney (I999).

\begin{tabular}{|l|l|}
\hline Species & Notes \\
\hline Potamopyrgus antipodarium & $\begin{array}{l}\text { Introduced sometime prior to 1852. Probable New Zealand } \\
\text { origin. }\end{array}$ \\
\hline Physa spp. & $\begin{array}{l}\text { One species (Physa fontinalis) is native, but other poorly-defined } \\
\text { species are probably 19th Century introductions from North } \\
\text { America. }\end{array}$ \\
\hline Menetus dilatatus & First recorded in 1869, origin probably eastern USA. \\
\hline Ferrissia wautieri & A very recent (1976) introduction from North Africa. \\
\hline Musculium transversum & First recorded in 1856, of North American origin \\
\hline Dreissena polymorpha & $\begin{array}{l}\text { An introduction from the Caspian/Black Sea around 1820, } \\
\text { probably via timber imported from the Baltic. }\end{array}$ \\
\hline
\end{tabular}

of open-country faunas, though now temperate rather than cold-climate ones, as prehistoric and historic farming activity transformed the British Isles into a mosaic of grassland, arable and woodland.

Several points are worthy of note. First, some species that colonised the British Isles as the last glacial maximum came to an end, and (relatively) warmer Late-glacial and early postglacial conditions persisted, themselves subsequently became extinct as conditions became warmer still and temperate woodland developed. Columella columella, for example, is an arctic-alpine species which was a characteristic element of the Late-glacial and early postglacial periods (Table I5), but which became extinct from the British Isles as conditions warmed further (Table I4). Second, it is also evident that it is not just species that can become extinct: communities or species-associations can too. Notwithstanding the actual geographical extinction of Columella columella it is evident that the association of the other species in Zone $z$ has no modern parallel within the British Isles, having only existed for the limited period of periglacial conditions in the Late-glacial and very early postglacial. Third, as vegetation changes followed temperature changes and the landscape became one of temperate mixed-woodland, thermophilous (i.e. warmth-loving) shade-requiring species such as Spermodea lamellata were able to move into the British Isles for the first time. The first few thousand years of the postglacial period was therefore a time in which the molluscan fauna of these islands was altering as a result of temperature, and later vegetation, changes. Some of our native species did not finally reach Britain until well into the postglacial period, just before the land bridge attaching the British Isles to the European mainland was cut off by rising sea level. This severing of the land bridge fixed our 'native' molluscan fauna and hindered the migration of other species from the European mainland which otherwise may also have become established here. Finally, it can be said that as a result of later human impacts these islands have a richer molluscan fauna than they would have had had woodland clearance not occurred (Kerney 1968). Without such clearance some of the open-country species which are now widespread and characteristic of grazed or otherwise managed land might well have been marginalised to the point of extinction. In addition, some of the more recent 'accidental' introductions (see Table 12) would not have become so readily established within wooded conditions. 


\section{Introductions and extinctions}

The species considered as introduced are given as Tables I2 and I3. It is noticeable that 2I terrestrial species are considered as introductions (Table I2), some 20 per cent of the entire current terrestrial molluscan fauna. Only two species seem to have been prehistoric introductions, the other is being Roman/Romano-British, medieval or more recent introductions. Only one (Helix pomatia-Figure 42) is considered a deliberate introduction, as a food source; the rest appear to have been 'accidental'.

The status of many of the freshwater and brackish species is less certain. Kerney (1999) only lists five species and elements of one taxon (Physa spp.) as definite introductions. They are all recent and the dates of first occurrences well documented (Table I3). However, a further I4 freshwater or brackish gastropods and seven freshwater bivalves are only listed as probably native or query (?) native. This uncertainty reflects the relative paucity of well-dated fossil occurrences as compared to terrestrial Mollusca.

Table I4 lists the terrestrial and freshwater species currently considered as once native but now extinct. As mentioned earlier, the majority of these are species that were able to colonise the British Isles during the Late-glacial or early postglacial period but were disadvantaged as temperate woodland conditions became fully established. Although these extinctions seem to be securely recorded, a word of caution is necessary. As the mapping scheme data accumulated, at least one species (Vertigo genesii an arctic-alpine species thought to have only inhabited the British Isles during the Late-glacial and early postglacial) was 're-discovered' as an extant species, albeit in a single locality in Teesdale (Coles and Colville 1980). It remains possible that some of

\begin{tabular}{|l|l|}
\hline Species & Notes \\
\hline Cochlicopa nitens & $\begin{array}{l}\text { A central and eastern European species which is known only from } \\
\text { UK Late-Glacial and early postglacial deposits (see Preece 1992 } \\
\text { and Davies 2006). }\end{array}$ \\
\hline Columella columella & $\begin{array}{l}\text { An arctic alpine species found only in Late-glacial and early } \\
\text { postglacial deposits in the UK. }\end{array}$ \\
\hline Discus ruderatus & $\begin{array}{l}\text { A Holarctic species found in early postglacial deposits but replaced } \\
\text { by Discus rotundatus between } 8630 \pm 120 \text { and } 7650 \pm 80 \text { BP (Preece } \\
\text { and Bridgland 1998; 1999). }\end{array}$ \\
\hline Trochoidea geyeri & $\begin{array}{l}\text { Seemingly extinct from much of the UK by the early-mid } \\
\text { postglacial as open country was replaced by closed woodland. } \\
\text { However, it was present at Gwithian, Cornwall, in the Bronze Age } \\
\text { but seems to have become extinct shortly after, possibly as a result } \\
\text { of competition from other helicellines. }\end{array}$ \\
\hline Helicopsis striata & $\begin{array}{l}\text { Extinction in early-mid postglacial due to loss of open habitat as } \\
\text { woodland cover increased. }\end{array}$ \\
\hline Nesovitrea petronella & $\begin{array}{l}\text { Presently a boreal-alpine species. Extinction from UK due to } \\
\text { postglacial warming. }\end{array}$ \\
\hline Margaritifera auricularia & $\begin{array}{l}\text { Climatic change (postglacial warming) probably responsible for } \\
\text { extinction. }\end{array}$ \\
\hline Pisidium vincentianum & $\begin{array}{l}\text { A cold water bivalve now found in western Siberia and The } \\
\text { Himalayas. Only found in early postglacial lake deposits in the UK. }\end{array}$ \\
\hline
\end{tabular}

TABLE I4. Terrestrial and freshwater species becoming extinct from the UK during the Holocene. Data from Kerney (I999) unless otherwise stated. 
the other colder-climate species listed in Table I4 may survive as isolated extant populations in remoter areas of the British Isles.

TABLE I5. Molluscan biozones from south-east England as detailed by Preece and Bridgland I999.

\begin{tabular}{|c|c|}
\hline Biozone & Characteristic species and dates \\
\hline Zone $y$ & $\begin{array}{l}\text { Pupilla muscorum, Vallonia spp. and Vitrina pellucida dominated faunas. Dated } \\
\text { from } 13,160 \pm 400 \mathrm{yr} \text { BP to just before } 11,530 \pm 160 \mathrm{yr} \text { BP and therefore } \\
\text { covering the pre-interstadial phase of the Late-glacial. }\end{array}$ \\
\hline Zone $z$ & $\begin{array}{l}\text { An open ground periglacial fauna with Pupilla muscorum, Trichia hispida, Abida } \\
\text { secale, Vallonia spp., Columella columella and Neosovitrea bammonis. Dated from } \\
\text { just before } 11,530 \pm 160 \mathrm{yr} \text { BP until } 9820 \pm 90 \mathrm{yr} \text { BP. Covering the Late-glacial } \\
\text { (Windemere or Allerød) Interstadial and (Loch Lomond or Younger Dryas) } \\
\text { Stadial phases of the Late-glacial period, as well as the very early postglacial } \\
\text { period. }\end{array}$ \\
\hline Zone $a$ & $\begin{array}{l}\text { As z but with Pupilla and other bare ground species declining and with } \\
\text { ecologically catholic species increasing. Appearance of Carychium tridentatum, } \\
\text { Vitrea spp. and Aegopinella spp.. Dated from } 9760 \pm 100 \mathrm{yr} \text { BP until before } \\
9530 \pm 75 \mathrm{yr} \text { BP and reflecting increasingly wooded conditions. }\end{array}$ \\
\hline Zone $b$ & $\begin{array}{l}\text { Expansion of Carychium and Aegopinella and otherwise generally a woodland } \\
\text { assemblage. First appearance and expansion of Discus ruderatus. Dated from } \\
\text { just before } 9460 \pm 140 \mathrm{yr} \text { BP until } 8630 \pm 120 \mathrm{yr} \text { BP. }\end{array}$ \\
\hline Zone $c$ & $\begin{array}{l}\text { D. ruderatus replaced by } D \text {. rotundatus Otherwise a closed woodland assemblage. } \\
\text { Dated from } 8630 \pm 120 \mathrm{yr} \text { BP until just before } 7650 \pm 80 \mathrm{yr} \text { BP. }\end{array}$ \\
\hline Zone $d$ & $\begin{array}{l}\text { A woodland fauna with the notable expansion of Oxycbilus cellarius, Spermodea } \\
\text { lamellata, Leiostyla anglica and Acicula fusca. Dated from } 7650 \pm 80 \mathrm{yr} \text { BP until } \\
\text { sometime before } 5620 \pm 90 \mathrm{yr} \text { BP. }\end{array}$ \\
\hline Zone $e$ & $\begin{array}{l}\text { Shade species decline. Re-emergence and expansion of open-ground species, } \\
\text { particularly Vallonia costata. Lower boundary dating to between } 5620 \pm 90 \text { to } \\
3980 \pm 70 \text { yrs BP, reflecting the diachronous nature of substantial prehistoric } \\
\text { woodland clearance. }\end{array}$ \\
\hline Zone $f$ & As Zone $e$ but with $H$. aspersa. From sometime before $2850 \pm 70 \mathrm{yr}$ BP. \\
\hline
\end{tabular}

Figure 42. Helix pomatia.

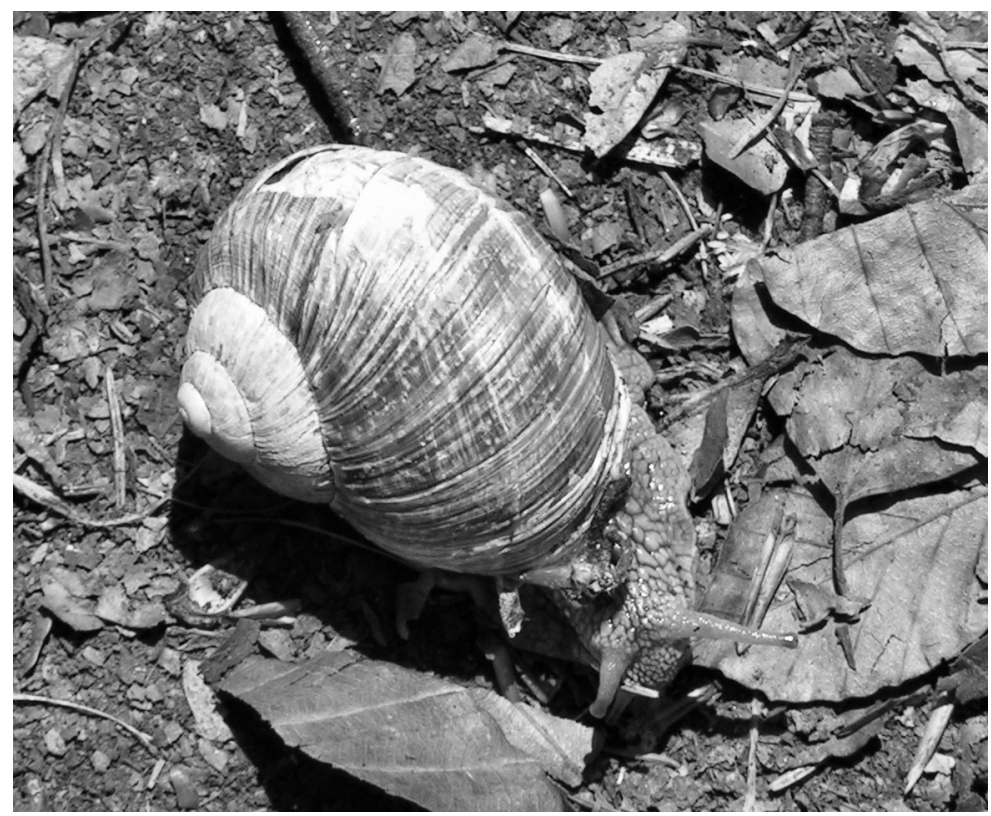




\section{Relict, declining and 'migrating' species}

Another feature of the national mapping scheme is that it is possible to consider which extant species are relict and which are declining. Relict species are those which were once more widespread under different climatic conditions (e.g. the cooler, drier conditions of the early postglacial) and are now generally disadvantaged but just about maintaining viable populations in a few localities where conditions allow. Vertigo genesii, mentioned above, comes into this group. Other examples include Vertigo modesta, Vitrea subrimata, Sphaerium solidum, Catinella arenaria, Pisidium conventus, and Pisidium lilljeborgi. Declining species are those which were once far more widespread but are threatened by human-induced habitat loss (e.g. Aplexa hypnorum and Lymnaea glabra suffering from loss of ditches and ponds), the effects of pollution (e.g. Myxas glutinosa and Segmentina nitida) or climatic cooling since the mid-postglacial climatic optimum (e.g. Pomatias elegans, Ena montana).

Some species show very strong evidence of northward migration due to longer-term climate change. Both Vertigo genesii and Vertigo geyeri are borealalpine species intolerant of warmth and have migrated northwards since the earlier postglacial period. Unlike Columella columella they have not yet become extinct, but future warming could severely threaten their existence in the British Isles. Conversely, some of the more recent introductions, particularly the 'Mediterranean' species (e.g. Theba pisana and Hygromia cinctella) which currently have a limited distribution due to frost intolerance may well expand their distributions in the same way that Monacha cantiana seems to have done over the last century (Kerney 1999). 